\title{
Technical Note: Effects of Adding Shade and Fans to a Feedbunk Sprinkler System for Preparturient Cows on Health and Performance
}

\author{
J. H. Urdaz, ${ }^{*}$ M. W. Overton, $†$ D. A. Moore, $\dagger^{1}$ and J. E. P. Santos $†$ \\ *Department of Large Animal Clinical Sciences, College of Veterinary Medicine, \\ University of Florida, Gainesville 32610-0136 \\ †Department of Population Health and Reproduction, University of California, Davis, \\ Veterinary Medicine Teaching and Research Center, Tulare 93274
}

\begin{abstract}
The purpose of this study was to examine the effects of adding shades and fans to a feedbunk-mounted sprinkler system on preparturient Holstein cows during summer heat stress. Outcome variables included postpartum milk production, changes in body condition score, changes in serum concentrations of nonesterified fatty acids (NEFA), and incidence of postparturient disorders. Four hundred and seventy-five prepartum multiparous cows, 250 to $257 \mathrm{~d}$ pregnant, were randomly allocated to 2 study pens. Treatments consisted of sprinklers over the feed bunk ( $\mathrm{n}=236)$; and sprinklers, fans, and shades over the feed bunk $(\mathrm{n}=239)$. Data were used from cows spending a minimum of $14 \mathrm{~d}$ in their assigned pen. After parturition, all cows were housed and managed under identical conditions. Data recorders in each pen recorded environmental temperature and humidity every $30 \mathrm{~min}$. Body condition scores were taken at study enrollment, parturition, and $60 \mathrm{~d}$ in lactation. Following parturition, the presence of retained placenta, metritis, milk fever, and displaced abomasum were recorded for the length of the study. Milk production was measured using twice-monthly Dairy Herd Improvement Association tests for the first $60 \mathrm{~d}$ in lactation. Blood was sampled twice weekly in 98 cows and analyzed for serum NEFA during the last $3 \mathrm{wk}$ before parturition. Cows spent approximately $28 \mathrm{~d}$ in their respective treatments. Average daily environmental temperature $( \pm \mathrm{SD})$ in the sprinkler only treatment was $26.4 \pm 7.2$ vs. $25.1 \pm 8.6^{\circ} \mathrm{C}$ in the shade, fans, and sprinkler treatment during the length of the trial. There was no difference in body condition score changes, incidence of postparturient disorders, or serum NEFA concentrations. There was a significant difference in total 60-d milk production, and an economic benefit over the preexisting cooling system.
\end{abstract}

Received July 9, 2005.

Accepted December 7, 2005.

${ }^{1}$ Corresponding author: dmoore@vmtrc.ucdavis.edu
Key words: preparturient, dairy cow, cooling, heat stress

Heat stress, defined as the point when heat gain of the cow overcomes the amount of heat loss (Shearer and Beede, 1990b), has important consequences for animal welfare and performance, and has been implicated as the most important reason for lower milk production during summer (Armstrong, 1994; Silanikove, 2000). Previous research targeted prevention (Silanikove, 2000) of heat stress in lactating cows and the application of cooling systems for lactating cows, which minimizes decreases in milk production during summer (Igono et al., 1985; Her et al., 1988; Verbeck et al., 1996; Thompson et al., 1999).

Little is known about the effects of cooling preparturient dairy cows during the last 3 wk of gestation on subsequent milk production and health. The 3 -wk period before parturition is an important period because fetal growth is most rapid around this time (Shearer and Beede, 1990a); birth weights of calves from cows exposed to heat stress are lower than those from nonheat-stressed cows (Collier et al., 1982b; Wolfenson et al., 1988). Initiation of milk synthesis takes place during the prepartum period, and could be affected by hormonal alterations caused by heat stress (Collier et al., 1982b; Ingvartsen and Andersen, 2000). Heat stress also reduces feed intake when temperatures are above 25 to $27^{\circ} \mathrm{C}$, with a marked impact above $30^{\circ} \mathrm{C}$ (NRC, 1981), which could influence tissue mobilization. Concentrations of NEFA in blood normally increase during the final days before parturition (Bertics et al., 1992). Concentrations of NEFA below $0.325 \mathrm{mEq} / \mathrm{L}$ in blood may indicate a positive energy balance in the preparturient dairy cow; cows between 14 and $2 \mathrm{~d}$ before calving with blood NEFA concentrations $>0.400 \mathrm{mEq} / \mathrm{L}$ are likely to be in negative energy balance (Cameron et al., 1998). Based on these observations, prepartum heat stress could influence milk production in the subsequent lactation as well as energy balance in the prepartum period.

The objectives of this study were to compare the effects and economics of ancillary cooling (sprinklers, 


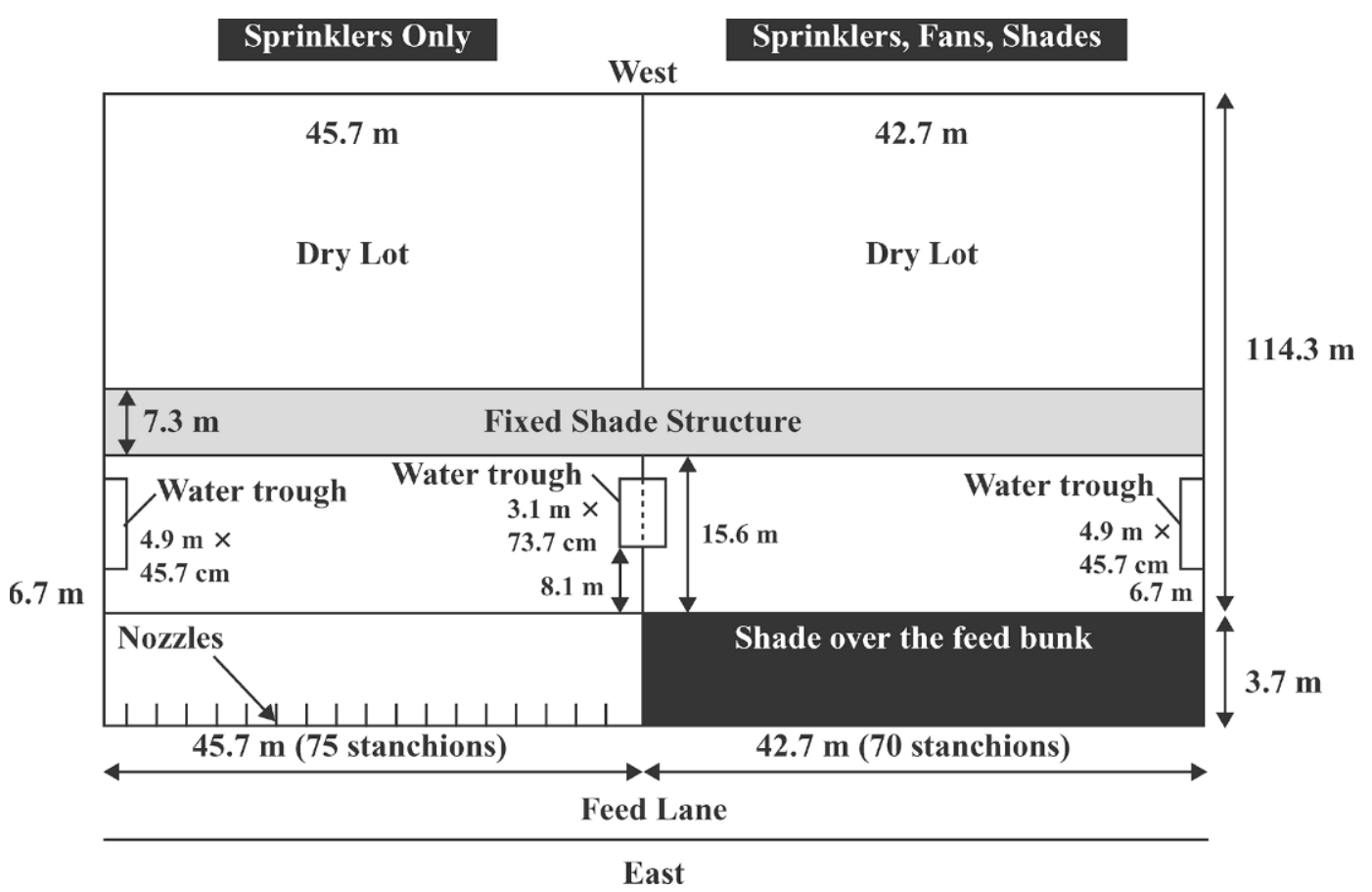

Figure 1. Plot view of 2 pens used in evaluating the effects of fans, sprinklers, and shades vs. sprinklers only on subsequent milk yield and animal health performance of 475 preparturient multiparous Holstein cows enrolled from June through September 2002.

fans, and shades) vs. feedbunk sprinklers alone for $3 \mathrm{wk}$ before parturition on risk for postparturient disorders, postparturient milk production, and adipose tissue mobilization. Study cows were enrolled on a central California, high-producing, commercial, 3,000-cow Holstein dairy herd with a rolling herd average of approximately $10,045 \mathrm{~kg} / \mathrm{yr}$, and an average daily milk production of $34.5 \mathrm{~kg} / \mathrm{cow}$. Lactating cows were milked twice daily in a double- 24 herringbone-type parlor and housed in freestall barns with approximately 216 cows per pen. Preparturient cows were housed in dry lots with shades in the lounging area. The vaccination program was typical for dairies in the region. A TMR supplemented with acidogenic salts and a lactating cow TMR were fed once daily during the immediate preparturient and the postparturient periods, respectively. The rations were formulated to meet the requirements for these groups according to guidelines established by the National Research Council (NRC, 2001).

Two identically structured pens were used, each measuring approximately $118 \mathrm{~m}$ long by $45 \mathrm{~m}$ wide and containing permanent shade structures in the lounging areas (Figure 1). The feed lanes, with self-locking stanchions, faced east. Sprinklers were in place over the feed bunk in 1 pen (S pen) with 75 stanchions. In the intervention pen that contained 70 stanchions, fans and shades were placed over the feed bunk in addition to the feedbunk sprinklers (SFS pen). The system of sprin- klers was set over the stanchions on the east side of the 2 pens. Low-pressure nozzles were mounted $1.7 \mathrm{~m}$ above the pen surface, spaced $1.5 \mathrm{~m}$ apart, and delivered approximately 1.4 to $1.8 \mathrm{~L} / \mathrm{min}$.

In the SFS pen, shade cloth (95\% shade) extended directly over a concrete surface behind the stanchion headlocks (Figure 2). The fixed metal framework was $5.5 \mathrm{~m}$ wide by $3.9 \mathrm{~m}$ high above the concrete surface in the front and $3.5 \mathrm{~m}$ high in the back, and supported a $42.7 \mathrm{~m}$ long by $4.6 \mathrm{~m}$ wide woven polypropylene cloth (Windtamer Tarps, Inc., Lemoore, CA). There was approximately $15.2 \mathrm{~m}^{2}$ of shade cloth/cow in the SFS treatment.

Within the SFS pen, an array of 7 fans were placed in the metal framework $6.1 \mathrm{~m}$ apart over the feed bunk at a height of $2.4 \mathrm{~m}$ above the concrete surface of the pen (Figure 2). All fans were 91.4-cm diameter circulation fans (Barnstormer, model \# VBS36F, J \& D Manufacturing Inc., Eau Claire, WI), positioned at a $30^{\circ}$ angle, and were rated for airflow of $317.2 \mathrm{~m}^{3} / \mathrm{min}$. Fans and sprinklers ran continuously from approximately 0900 to $2000 \mathrm{~h}$ during the trial.

Between June 20 and September 12, 2002, 524 nonlactating Holstein cows were randomly allocated to 1 of the 2 pens at a rate of approximately 40/wk. All cows were entering their second or greater lactation and between 250 to $257 \mathrm{~d}$ pregnant at enrollment (based on farm records). Cows were required to spend a mini- 


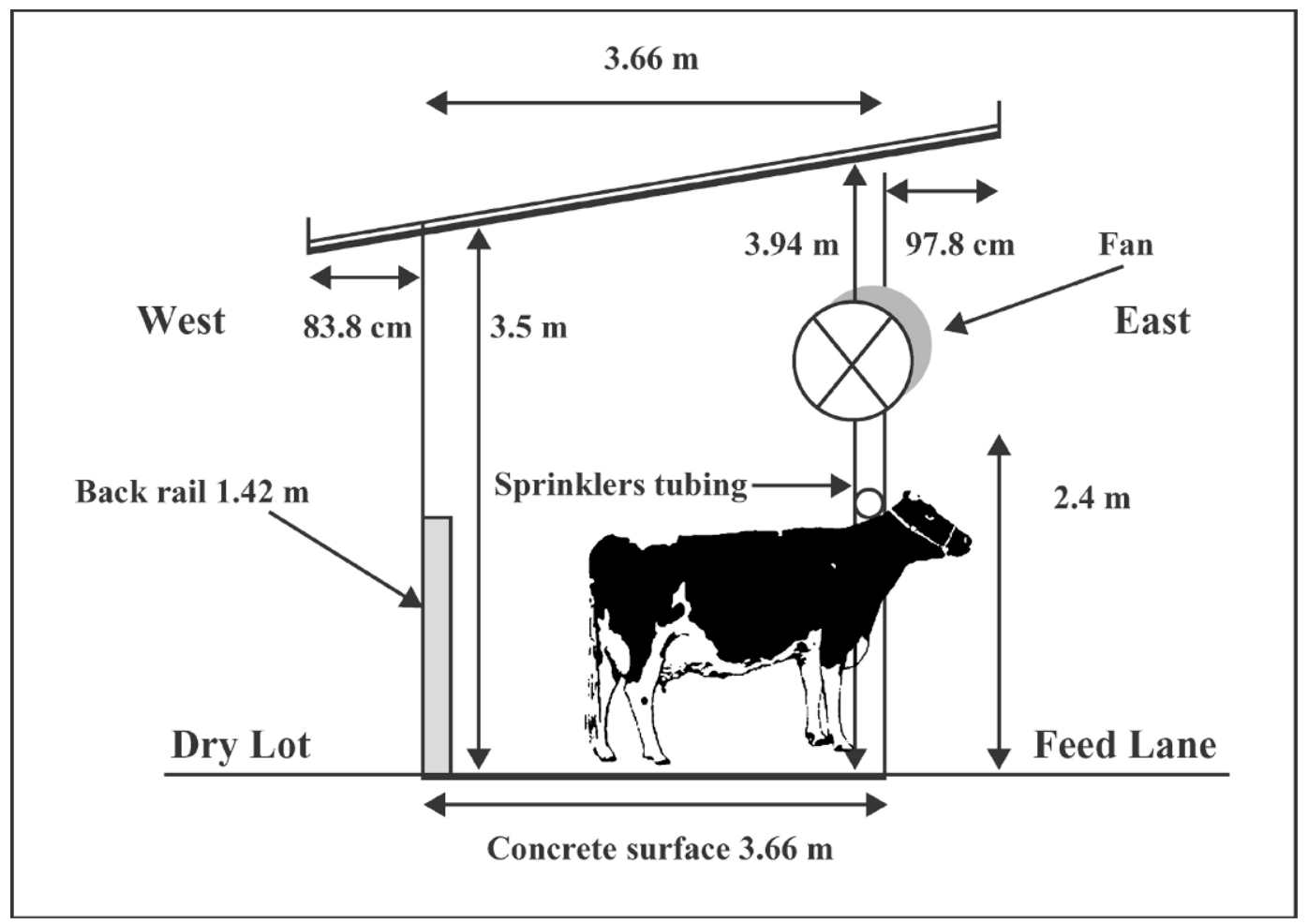

Figure 2. Cross section of the feed bunk, fan, and sprinkler cooling system used in evaluating the effects of fans, sprinklers, and shades vs. sprinklers only on subsequent milk production and animal health of preparturient multiparous Holstein cows enrolled from June through September 2002.

mum of $14 \mathrm{~d}$ in their assigned pen before parturition for their data to be analyzed. Each cow was monitored for $60 \mathrm{~d}$ after parturition. A sample size of 216 cows per cooling group was calculated by establishing an expected difference in milk production of $2.3 \mathrm{~kg} / \mathrm{d}$ in milk between the SFS and S pens based on previously published work (Wolfenson et al., 1988) using a level of significance of 0.05 and $80 \%$ power. An average milk production of $31.8 \mathrm{~kg}$ ( $\mathrm{SD}=11.4 \mathrm{~kg}$ ) was obtained by using milk production estimates from the previous summer's first monthly milk production for multiparous cows from DHIA records of the herd. An additional 10\% for potential loss to follow up was added, increasing the sample sizes to 238 cows per group. After parturition, all cows were housed together in the lactating group and managed under identical conditions.

Ambient temperature and relative humidity (RH) were recorded every $30 \mathrm{~min}$ by computerized data recorders (HOBO H8 Pro Series H08-032-08, Onset Computer Corp., Bourne, MA), operated by a computer software program (BoxCar Pro 4.0 Starter Kit, Onset Computer Corp.). Temperature and $\mathrm{RH}$ accuracy were within $\pm 0.2^{\circ} \mathrm{C}$ and $\pm 3 \%$, respectively. Two recorders, one in each pen, were set at a height of $1.4 \mathrm{~m}$ and centralized on a back rail over the concrete pen surface
(Figure 2) and recorded data from June 20 to October 20,2002 . The equation used to calculate temperaturehumidity index (THI) in this study was: $\mathrm{THI}=\mathrm{td}-$ $(0.55-0.55 \mathrm{RH} / 100)(\mathrm{td}-58)$, where td is the dry bulb temperature (in ${ }^{\circ} \mathrm{F}$ ) and $\mathrm{RH}$ is relative humidity expressed as a percentage (NOAA, 1976). For each 24$\mathrm{h}$ period, average THI was calculated using average ambient temperature and average $\mathrm{RH}$. The number of preparturient days a cow spent with a daily average THI $>72$ was calculated to reflect the heat-stress duration. The proportion of each cow's preparturient days under heat stress was calculated from the days each cow spent over a THI of 72 divided by the total days in the pen.

Health and production information were gathered onfarm. Cows were body condition scored (Ferguson et al., 1994) at the time of enrollment (movement into the preparturient pen), at parturition, and at approximately 60 DIM. Three trained farm personnel diagnosed all postparturient disorders. Retained placenta was defined as the presence of fetal membranes visible at the vulva for more than $24 \mathrm{~h}$ after calving (Kelton et al., 1998). Metritis was defined as the presence of visual or olfactory appreciation of a fetid serosanguineous discharge during the first $10 \mathrm{~d}$ after calving 
(Overton et al., 2003). The diagnosis of milk fever was based upon the cow's inability to rise within $72 \mathrm{~h}$ of calving, with successful correction after administration of an i.v. calcium solution (Deluyker et al., 1991). Displaced abomasum was defined by the detection of a high-pitched ping between the 9 th and 12 th ribs at the level of the paralumbar fossa in the left or right abdominal wall (Kelton et al., 1998). Occurrences of postparturient disorders were recorded daily during the length of the study. Milk yield was evaluated at approximately 15-d intervals for the first 60 DIM under DHIA testing procedures (Kings County DHI, Hanford, CA).

Aseptic blood samples were drawn from the median coccygeal vein twice weekly for 3 wk before parturition approximately 30 min after feeding on d 18, 14, 11, 7, 4 , and 1 before expected parturition from a subsample of 98 cows (S, $n=47$; SFS, $n=51$ ). Five hundred eightyeight serum samples were handled and subsequently analyzed for NEFA concentration using previously described methods (Johnson and Peters, 1993). Average intraassay coefficient of variation was $3.67 \%$.

Body condition scores (rank values) and BCS changes were compared between treatments using the KruskalWallis nonparametric test. Two BCS changes were calculated: 1) BCS at parturition from BCS at prepartum enrollment, and 2) BCS at 60 DIM from BCS at parturition. Significant BCS loss in the preparturient period was defined as a loss of BCS $>0.25$ units between enrollment and parturition. Significant BCS loss after parturition was defined as a loss of $>0.25$ units of BCS between parturition and 60 DIM.

Each postparturient disease occurrence was expressed as lactational incidence risk; the percentage of cows experiencing a disorder within 60 DIM (Grohn et al., 1990; Rajala and Grohn, 1998). $\chi^{2}$ Analysis and the Fisher Exact Test were used to compare differences in postparturient disorders from S and SFS treatments.

Total milk production, as calculated from early lactation curves for each cow, was modeled for group effects. Milk production data from cows with at least 3 milk weights before 60 DIM $(\mathrm{n}=305)$ were fitted using the quadratic formula: Milk yield $\mathrm{Y}=\mu+\mathrm{DIM}+\mathrm{DIM}^{2}$, where DIM = days in lactation at each test. The equation was integrated and the total area under the curve (total milk yield) within the first 60 DIM was estimated for each cow. The 60-d milk yield was analyzed using a GLM (PROC GLM in SAS; SAS Institute, Inc., Cary, NC) with treatment as class. The full model was:

$$
\begin{gathered}
\mathrm{Y}=\mu+\text { GROUP }+ \text { LCTGP }+ \text { DIM }+ \text { PPD + DINCUC } \\
+ \text { CUWTLOSS }+ \text { FRWTLOSS }_{\mathrm{i}} \\
+ \text { HEATSTRESSDAYS or PROPSTRESS }
\end{gathered}
$$

where GROUP $=$ additional cooling or not; $\mathrm{LCTGP}=1$, 2 , or $>2$ lactations; DIM = days in lactation; PPD = postpartum disease (yes/no); DINCUC = days spent in the prepartum pen; CUWTLOSS $=$ loss of $0.25 \mathrm{BC}$ between movement to the prepartum pen and parturition $(\mathrm{i}=0)$; FRWTLOSS $=$ a loss of more than 0.25 BCS between parturition and 60 DIM $(\mathrm{i}=1)$ or a loss of 0.25 BCS or less $(i=0)$, and where HEATSTRESSDAYS = total number of days spent under THI $>72$ in the prepartum pen, PROPSTRESS = proportion of prepartum days spent under THI $>72$.

Data on serum NEFA concentrations were analyzed using a mixed model with unstructured covariance. In PROC Mixed in SAS, the specific mixed model was as follows: $\mathrm{Y}=\mu+$ GROUP $_{\mathrm{i}}+$ PERIOD $_{\mathrm{J}}$, where GROUP $=$ treatment ( $\mathrm{i}=\mathrm{S}$ and SFS) and PERIOD = days before expected parturition $(\mathrm{j}=18,14,11,7,4$ or 1$)$. For all tests, $P<0.05$ was considered significant.

Two hundred thirty-six and 239 cows spent at least 2 wk in the S pen and SFS pen, respectively. Fortynine of the original 524 enrolled cows were excluded because they spent fewer than $14 \mathrm{~d}$ in the treatment pens $(n=26)$; aborted, died or were culled before completion of the treatments $(n=9)$; or were in the treatment pens after the cooling system was removed $(\mathrm{n}=14)$. The 2 groups were similar for previous 305-d mature equivalent milk production, BCS at enrollment, average days in the preparturient pen, and lactation group distribution $(P>0.34)$.

A total of 5,136 temperature and humidity recordings were analyzed. Mean environmental temperatures ( \pm $\mathrm{SD})$ during the studied period were $26.4 \pm 7.2^{\circ} \mathrm{C}$ and $25.1 \pm 8.6^{\circ} \mathrm{C}$ for the $\mathrm{S}$ and SFS pens, respectively. Ambient temperature above 25 to $26^{\circ} \mathrm{C}$ may limit reproductive performance and milk yield (Berman et al., 1985). Mean THI ( \pm SD) during the study was $71.7 \pm 10.7$ and $70.7 \pm 9.3$ for the S and SFS pens, respectively (Figure 3). A THI value greater than 72 is considered an indication of heat stress in cattle (Johnson, 1987) and can lower milk yield by $0.2 \mathrm{~kg} / \mathrm{d}$ per unit of THI above 72 in lactating cows (Ravagnolo et al., 2000). Cows in treatment $\mathrm{S}$ spent a greater proportion of their preparturient days under heat stress than did cows in the SFS treatment ( 60 vs. $48 \% ; P=0.0003$ ).

Body condition scores at parturition taken after 7 DIM were excluded from analysis. Body condition at enrollment, parturition, and 60 DIM as well as BCS changes did not differ between treatments $(P>0.10)$, which suggests that additional cooling did not affect BCS change, consistent with other research (Wolfenson et al., 1988).

Overall, lactational incidence risks for retained placenta, milk fever, and displaced abomasum were consistent with reported frequencies of these disorders (Kel- 


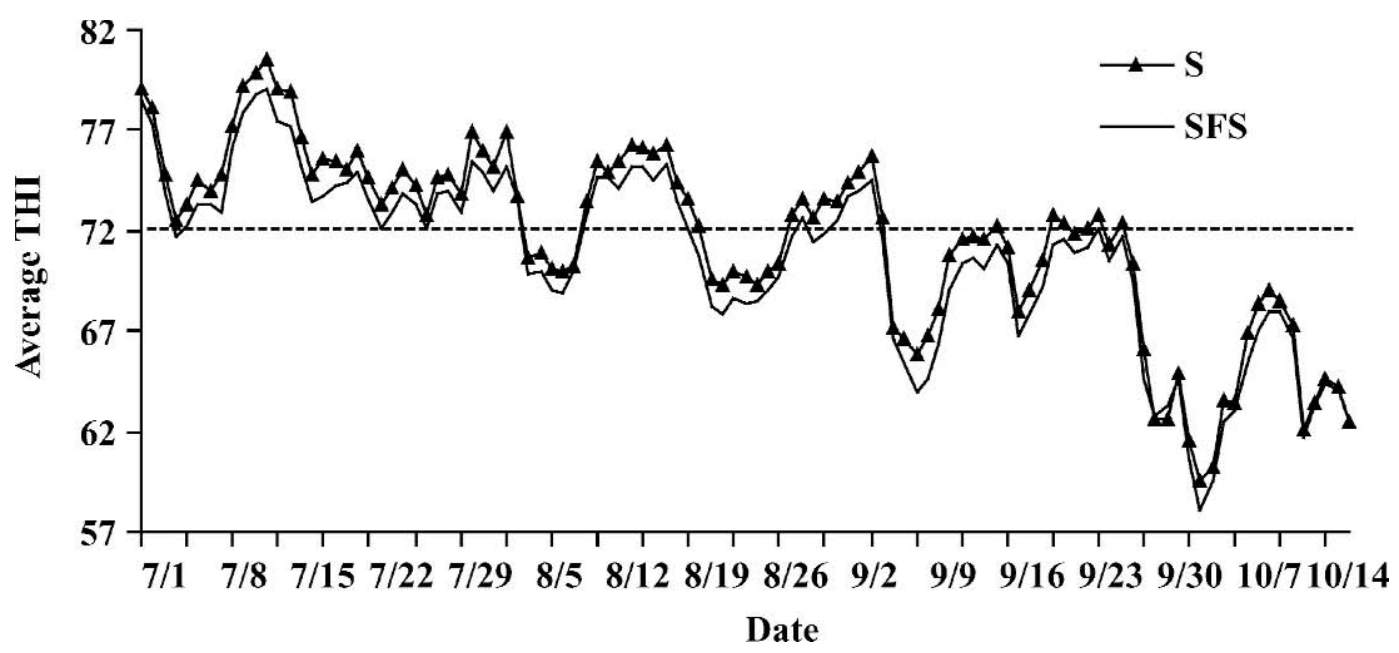

Figure 3. Average temperature-humidity index (THI) recorded in the 2 pens in a study evaluating the effects of fans, sprinklers, and shades (SFS) vs. sprinklers only (S) on subsequent milk and animal health performance of 475 preparturient multiparous Holstein cows from July 1, 2002 to October 15, 2002. The dashed line denotes a THI equal to 72 (the cut-off level for heat stress).

ton et al., 1998; Rajala and Grohn, 1998; Rajala-Schultz et al., 1999). Lactational incidence risk of metritis was low in our study, at $1.7 \%$. In a meta-analysis, reported ranges for metritis were 2.2 to $37.3 \%$ (Kelton et al., 1998). Metritis may have been truly low or, more likely, was under-reported. For cows in SFS and S, the proportion that developed retained placenta (2.3 vs. $2.7 \%$ ), metritis (1.1 vs. $0.6 \%)$, milk fever (0.8 vs. $0.8 \%)$, and displaced abomasum (0.6 vs. $1.1 \%$ ) was not significantly different.

Serum NEFA concentrations increased between d 18 and $\mathrm{d} 1$ prepartum, similar to reports for normal preparturient dairy cows (Bertics et al., 1992; Kaneene et al., 1997; Holcomb et al., 2001; Rabelo et al., 2003). Least squares means for serum NEFA at d 18 to d 1 before parturition ranged from 0.086 to $0.390 \mathrm{mEq} / \mathrm{L}$. Average $( \pm$ SEM) concentration and the range of concentration for the $\mathrm{S}$ treatment were $0.171 \pm 0.02 \mathrm{mEq} / \mathrm{L}$ and 0.020 to $1.44 \mathrm{mEq} / \mathrm{L}$, respectively. Serum NEFA concentration for the SFS treatment averaged $0.199 \pm 0.02 \mathrm{mEq} /$ $\mathrm{L}$ and ranged from 0.022 to $1.54 \mathrm{mEq} / \mathrm{L}$. The method of cooling of prepartum cows had no apparent effect $(P=0.29)$ on serum concentrations of NEFA, consistent with previous work (Collier et al., 1982a).

Using area-under-the-curve estimates of total milk production for the first 60 DIM from 304 cows with at least 3 tests before $60 \mathrm{DIM}$, cows in the S group produced less $(P=0.04)$ milk than cows in the SFS group (Table 1), with least squares mean estimates of 2,324 $\mathrm{kg}$ for the $\mathrm{S}$ group and $2,408 \mathrm{~kg}$ for the SFS group. Neither BCS loss before or after calving, presence of postpartum disease, total prepartum days spent under heat stress, nor proportion of prepartum days spent under heat stress were associated with 60-d total milk production.

To estimate the potential economic benefit of the SFS intervention, a partial budget was created to estimate the marginal costs and returns of the new system (Table 2). Marginal capital costs include the cost of purchasing and installing the fans, metal frame, and shade cloth. Annual operating costs include an estimate for routine maintenance and cleaning of fans, electricity required to power the fans, and a marginal $0.6 \mathrm{~kg}$ of DM that cooled cows might consume because of improved cooling. Economic returns from the SFS system is the addi-

Table 1. Results ${ }^{1}$ of analysis using the GLM procedure to evaluate the effects of preparturient pen fans, sprinklers, and shades vs. sprinklers only on the area-under-the-curve estimates of milk production for the first 60 d into lactation for 305 preparturient multiparous Holstein cows

\begin{tabular}{lll}
\hline & $\begin{array}{l}\text { Regression } \\
\text { coefficient } \\
\text { (kg) }\end{array}$ & \\
Predictor variable & $2,380.4$ & $P$-value \\
\hline Intercept & -84.3 & 0.00 \\
Sprinklers only & $\begin{array}{l}\text { Referent } \\
\text { Sprinklers, fans, and shades }\end{array}$ & 0.04 \\
Lactation 2 & -114.2 & 0.04 \\
Lactation 3 & -60.9 & 0.34 \\
Lactation $>4$ & $\begin{array}{c}\text { Referent } \\
\text { Days in lactation at test day }\end{array}$ & \\
Days in prepartum pen 14 to 21 d & -180.1 & 0.02 \\
Days in prepartum pen 22 to 27 d & -84.6 & 0.03 \\
Days in prepartum pen 28 to 34 & -5.9 & 0.21 \\
Days in prepartum pen >34 & Referent & 0.93 \\
Postpartum disease-No & 112.4 & 0.24 \\
Postpartum disease-Yes & Referent & \\
\hline
\end{tabular}

${ }^{1}$ Regression $F=2.79 ; P>\mathrm{F}=0.00 ; \mathrm{R}^{2}=0.07$; root mean square error $=3.77$. 
Table 2. Projected economic returns for preparturient pen fans, sprinklers, and shades vs. sprinklers only based on marginal milk production for the first $60 \mathrm{~d}$ into lactation for preparturient multiparous Holstein cows enrolled from June to October 2002

\begin{tabular}{|c|c|}
\hline Period (yr) & 5 \\
\hline Fans used, no. & 7 \\
\hline Cows cooled/summer & 239 \\
\hline Interest rate (cost of capital) & $7.0 \%$ \\
\hline Cows culled in first $60 \mathrm{~d}(\%)$ & $10.0 \%$ \\
\hline Median DIM at culling & 25 \\
\hline Net no. of cow-days to benefit & 13,504 \\
\hline \multicolumn{2}{|l|}{ Capital costs: } \\
\hline Fans, shade cloth, frame, and installation & $\$ 7,040.00$ \\
\hline Residual value of capital equipment after $5 \mathrm{yr}$ & $\$ 1,500.00$ \\
\hline Annual capital costs & $\$ 1,456.15$ \\
\hline \multicolumn{2}{|l|}{ Operating costs (per yr): } \\
\hline Maintenance and electricity for operation & $\$ 450.54$ \\
\hline Marginal feed for dry cows & $\$ 326.24$ \\
\hline Annual operating costs & $\$ 776.78$ \\
\hline Total annual costs & $\$ 2,232.93$ \\
\hline \multicolumn{2}{|l|}{ Returns: } \\
\hline Additional milk over 60 DIM, kg/d & 1.4 \\
\hline Marginal milk price for additional milk & $\$ 0.23$ \\
\hline Total annual benefit (milk returns) & $\$ 4,363.66$ \\
\hline Profit per year (based on milk only) & $\$ 2,130.72$ \\
\hline Profit per cow & $\$ 8.92$ \\
\hline Percentage profit per dollar spent per year & $95 \%$ \\
\hline
\end{tabular}

tional $84.3 \mathrm{~kg}$ of milk over 60 DIM for cows completing a 14-d stay in the preparturient pen and successfully completing the 60 -d lactation period. With the $1.4-\mathrm{kg}$ increase in milk per day, we assumed that cows would eat an additional $0.6 \mathrm{~kg}$ of DM feed, netting a marginal milk price of $\$ 0.23 / \mathrm{kg}$ of milk. Subtracting the annual operating costs from the returns yields an annual profit of $\$ 2,131 /$ cow.

Cooling preparturient dairy cows with shades, fans, and sprinklers compared with only sprinklers improved total $60-\mathrm{d}$ milk production by $84.3 \mathrm{~kg} / \mathrm{cow}$, and increased profitability by $\$ 2,131$ per cow. Although cows in the SFS treatment were less exposed to heat stress during the prepartum period, it was not sufficient to influence changes in BCS or prepartum serum NEFA concentrations.

\section{ACKNOWLEDGMENTS}

The authors thank the dairy farm team for their assistance and Diana Kinder, Daniella Resende, and William Sischo for help with data management and statistics. The study was supported by the American Association of Bovine Practitioners (AABP) Research Assistantship. Additional support was obtained from the University of California, Davis, Master of Preven- tive Veterinary Medicine Research Fund, and supplemental funds from D. A. Moore.

\section{REFERENCES}

Armstrong, D. V. 1994. Heat stress interaction with shade and cooling. J. Dairy Sci. 77:2044-2050.

Berman, A., Y. Folman, M. Kaim, M. Mamen, Z. Herz, D. Wolfenson, A. Arieli, and Y. Graber. 1985. Upper critical temperatures and forced ventilation effects for high-yielding dairy cows in a subtropical climate. J. Dairy Sci. 68:1488-1495.

Bertics, S. J., R. R. Grummer, C. Cadorniga-Valino, and E. E. Stoddard. 1992. Effect of prepartum dry matter intake on liver triglyceride concentration and early lactation. J. Dairy Sci. 75:19141922.

Cameron, R. E., P. B. Dyk, T. H. Herdt, J. B. Kaneene, R. Miller, H. F. Bucholtz, J. S. Liesman, M. J. Vandehaar, and R. S. Emery. 1998. Dry cow diet, management, and energy balance as risk factors for displaced abomasum in high producing dairy herds. J. Dairy Sci. 81:132-139.

Collier, R. J., D. K. Beede, W. W. Thatcher, L. A. Israel, and C. J. Wilcox. 1982a. Influences of environment and its modification on dairy animal health and production. J. Dairy Sci. 65:2213-2227.

Collier, R. J., S. G. Doelger, H. H. Head, W. W. Thatcher, and C. J. Wilcox. 1982b. Effects of heat stress during pregnancy on maternal hormone concentrations, calf birth weight and postpartum milk yield of Holstein cows. J. Anim. Sci. 54:309-319.

Deluyker, H. A., J. M. Gay, L. D. Weaver, and A. S. Azari. 1991. Change of milk yield with clinical diseases for a high producing dairy herd. J. Dairy Sci. 74:436-445.

Ferguson, J. D., D. T. Galligan, and N. Thomsen. 1994. Principal descriptors of body condition score in Holstein cows. J. Dairy Sci. 77:2695-2703.

Grohn, Y. T., H. N. Erb, C. E. McCulloch, and H. S. Saloniemi. 1990. Epidemiology of mammary gland disorders in multiparous Finnish Ayrshire cows. Prev. Vet. Med. 8:241-252.

Her, E., D. Wolfenson, I. Flamenbaum, Y. Folman, M. Kaim, and A. Berman. 1988. Thermal, productive, and reproductive responses of high yielding cows exposed to short-term cooling in summer. J. Dairy Sci. 71:1085-1092.

Holcomb, C. S., H. H. Van Horn, H. H. Head, M. B. Hall, and C. J. Wilcox. 2001. Effects of prepartum dry matter intake and forage percentage on postpartum performance of lactating dairy cows. J. Dairy Sci. 84:2051-2058.

Igono, M. O., B. J. Steevens, M. D. Shanklin, and H. D. Johnson. 1985. Spray cooling effects on milk production, milk, and rectal temperatures of cows during a moderate temperate summer season. J. Dairy Sci. 68:979-985.

Ingvartsen, K. L., and J. B. Andersen. 2000. Integration of metabolism and intake regulation: A review focusing on periparturient animals. J. Dairy Sci. 83:1573-1597.

Johnson, H. D. 1987. Bioclimate effects on growth, reproduction and milk production. Pages 35-37 in Bioclimatology and the adaptation of livestock. H. D. Johnson, ed. Elsevier, Amsterdam, The Netherlands.

Johnson, M. M., and J. P. Peters. 1993. Technical note: An improved method to quantify nonesterified fatty acids in bovine plasma. J. Anim. Sci. 71:753-756.

Kaneene, J. B., R. Miller, T. H. Herdt, and J. C. Gardiner. 1997. The association of serum nonesterified fatty acids and cholesterol, management and feeding practices with peripartum disease in dairy cows. Prev. Vet. Med. 31:59-72.

Kelton, D. F., K. D. Lissemore, and R. E. Martin. 1998. Recommendations for recording and calculating the incidence of selected clinical diseases of dairy cattle. J. Dairy Sci. 81:2502-2509.

National Research Council. 2001. Nutrient Requirements of Dairy Cattle. National Academy Press, Washington, DC.

National Research Council (Committee on Animal Nutrition, Subcommittee on Environmental Stress). 1981. Feed intake. Pages 27-34 in Effect of environment on nutrient requirements of domestic animals. National Academy Press, Washington, DC. 
NOAA. 1976. Livestock Hot Weather Stress. Operations Manual Letter C-31-76. NOAA, Kansas City, MO.

Overton, M. W., W. M. Sischo, and J. P. Reynolds. 2003. Evaluation of effect of estradiol cypionate administered prophylactically to postparturient dairy cows at high risk for metritis. J. Am. Vet. Med. Assoc. 223:846-851.

Rabelo, E., R. L. Rezende, S. J. Bertics, and R. R. Grummer. 2003. Effects of transition diets varying in dietary energy density on lactation performance and ruminal parameters of dairy cows. J. Dairy Sci. 86:916-925.

Rajala, P. J., and Y. T. Grohn. 1998. Effects of dystocia, retained placenta, and metritis on milk yield in diary cows. J. Dairy Sci. 81:3172-3181.

Rajala-Schultz, P. J., Y. T. Grohn, and C. E. McCulloch. 1999. Effects of milk fever, ketosis, and lameness on milk yield in dairy cows. J. Dairy Sci. 82:288-294.

Ravagnolo, O., I. Misztal, and G. Hoogenboom. 2000. Genetic component of heat stress in dairy cattle, development of heat index function. J. Dairy Sci. 83:2120-2125.
Shearer, J. K., and D. K. Beede. 1990a. Heat stress: 2. Effects of high environmental temperature on production, reproduction, and health of dairy cattle. Agri-Practice 11:6-16.

Shearer, J. K., and D. K. Beede. 1990b. Thermoregulation and physiological responses of dairy cattle in hot weather. Agri-Practice 11:5-18.

Silanikove, N. 2000. Effects of heat stress on the welfare of extensively managed domestic ruminants. Livest. Prod. Sci. 67:1-18.

Thompson, J. A., M. Brimacombe, J. A. Calvin, M. A. Tomaszewski, T. J. Davidson, and D. D. Magee. 1999. Effects of environmental management on seasonal decrease in milk production in dairy cattle. J. Am. Vet. Med. Assoc. 214:85-88.

Verbeck, R. T., T. Ross, and J. F. Smith. 1996. Effects of a spray and fan cooling system on milk yield and components, body condition, and respiration rates of early lactation cows in a hot dry climate. J. Anim. Sci. 74(Suppl. 1):32.

Wolfenson, D., I. Flamenbaum, and A. Berman. 1988. Dry period heat stress relief effects on prepartum progesterone, calf birth weight, and milk production. J. Dairy Sci. 71:809-818. 